\title{
LINKING PROJECTS TO BUSINESS STRATEGY THROUGH PROJECT PORTFOLIO MANAGEMENT
}

\author{
A.J. Buys ${ }^{1^{*}}$ and M.J. Stander ${ }^{2}$ \\ ${ }^{1,2}$ Graduate School of Technology Management \\ University of Pretoria, South Africa \\ 1aj.buys@up.ac.za, ${ }^{2}$ mjstander@webmail.co.za
}

\begin{abstract}
In many organisations, a chasm exists between the development of strategy and its successful implementation. Failure to cross this chasm may ultimately result in strategy failure and the loss of competitive advantage, profits, and employment. Project Portfolio Management (PPM) is theorised as a management methodology that links a portfolio of projects to the business strategy. However, current literature lacks empirical evidence of the levels of employment, functionality, and success of the Project Portfolio Management approach in South Africa. A survey of respondents in 32 technology organisations was used to analyze the reasons for the following: strategy implementation and project delivery failure in South African technology organisations; the South African situation regarding the chasm that exists in many organisations between strategy development and successful strategy implementation; and the extent to which - and with what success - Project Portfolio Management is employed in South African technology organisations.
\end{abstract}

\section{OPSOMMING}

In baie organisasies bestaan daar 'n gaping tussen strategie-ontwikkeling en suksesvolle strategie-implementering. Die onvermoë om die gaping te oorbrug sal uiteindelik lei tot strategiefaling en die verlies van mededingende voordeel, winste, en werksgeleenthede. Projekportefeuljebestuur (PPB) word voorgehou as 'n bestuursmetodologie wat 'n portefeulje van projekte koppel aan die besigheidstrategie. Bestaande literatuur gaan egter mank aan empiriese bewyse ten opsigte van die vlakke van indiensneming, funksionaliteit, en sukses van die Projekportefeuljebestuursbenadering in Suid-Afrika. 'n Opname van respondente in 32 tegnologie-organisasies is gebruik om die volgende aspekte te ondersoek: die redes vir falings in strategie-implementering en projekaflewering in Suid-Afrikaanse tegnologie-organisasies; die Suid-Afrikaanse situasie rakende die gaping wat bestaan tussen strategie-ontwikkeling en suksesvolle strategie-implementering; en die mate waartoe en met watter mate van sukses Projekportefeuljebestuur in Suid-Afrikaanse tegnologieorganisasies gebruik word.

\footnotetext{
${ }^{1 *}$ Corresponding author

${ }^{2}$ This author was enrolled for an MEng (Project Management) degree at the Graduate School of Technology Management, University of Pretoria.
} 


\section{INTRODUCTION}

Managers, many of them participants in strategic planning in a range of companies, have expressed their concern that in today's dynamic business environment they face misalignment between their companies' long- and short-term strategic objectives, and the corresponding ability effectively to identify, manage, and successfully deliver on the projects targeted to achieve the business's objectives [1]. Past research [2], [3], [4], [1], [5] has found that in many organisations a chasm exists between strategy development and successful strategy implementation. Failure to cross this chasm may ultimately result in strategy failure and a loss of competitive advantage, profits, and employment [6].

This study investigates Project Portfolio Management (PPM) as a possible solution to this management problem. Although PPM has been well described in the literature [7], [8], [9], [10], [11], there is a lack of empirical studies on the employment of PPM by organisations and the success with which it is employed. Is PPM the 'magic bullet' that closes the chasm between strategy development and successful implementation?

The objectives of the research were to determine to what extent - and with what success PPM is employed by South African organisations.

\section{CONCEPTUAL FRAMEWORK}

Past research [2], [3], [4], [1] has found that some of the most common reasons why strategic plans are not implemented successfully are those listed in Table 1.

\begin{tabular}{|l|}
\hline Daily work activities are not separated from strategic 'breakthrough' activities \\
\hline Pre-occupied resources \\
\hline Vague mission statements with limited deployment in the organisation \\
\hline Vague vision statements with limited deployment in the organisation \\
\hline Lack of operational data analysis during strategic planning sessions \\
\hline Lack of periodic progress review and process improvement \\
\hline Projects are not aligned with the strategic intent of the organisation \\
\hline
\end{tabular}

Table 1: Common reasons why strategic plans are not implemented successfully

Projects are often not delivered on time, within budget, or within scope or specifications. Past research [2], [3], [4], [1] has found that some of the most common reasons why projects fail are those listed in Table 2.

\begin{tabular}{|l|}
\hline Project and resource managers often fight over resources \\
\hline There are too many projects and too few resources \\
\hline Priorities of projects frequently change, with resources being reassigned \\
\hline Senior managers unilaterally approve and release projects without regard for capacity \\
\hline Projects are not linked to the goals of the organisation \\
\hline
\end{tabular}

Table 2: Common reasons why projects fail

Project Portfolio Management (PPM) has been proposed as a possible solution to this management problem. A company's Project Portfolio consists of one or more programmes of related projects, as shown in Figure 1. 


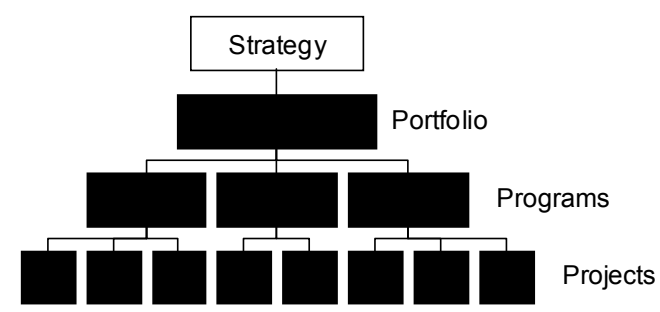

Figure 1: Hierarchy of projects (Adapted from King [8])

Project Portfolio Management (PPM) is a management process designed to help an organisation acquire and view information about all of its projects, and then sort and prioritise each project according to certain criteria, such as strategic value, impact on resources, cost, and so on. Kendall and Rollins [12] define the purpose of PPM as ensuring that the collection of projects chosen and completed meets the goals of the organisation. Ciliberti [13] states that projects should be included in a portfolio based on their alignment with business strategy. The expectation is that improved strategy delivery will be gained through aligning the project portfolio with the strategic intent of the organisation. The objectives of PPM are therefore: 1) to become conscious of all the individual listings in the company's project portfolio, 2) to develop an overall view and a deeper understanding of the portfolio as a whole, 3 ) to allow sensible sorting, adding, and removing of items from the portfolio based on their costs, benefits, and alignment with long-term strategies and goals, and 4) to allow the company to get the highest return from resources invested [14].

Organisations that have formally adopted PPM should be actively employing and managing a process that achieves the following key criteria and responsibilities [12]:

- Determining a viable project mix capable of meeting the strategic goals of the organisation.

- Balancing the project portfolio (e.g. risk vs reward, research vs development).

- Monitoring the planning and execution of chosen projects.

- Analysing portfolio performance and ways to improve it.

- Evaluating new opportunities against the current portfolio and comparatively with each other, taking into account the organisation's project execution capacity.

- Providing information and recommendations to decision makers at all levels.

However, the realisation of these responsibilities takes time to be achieved. We therefore propose three stages of PPM employment, as shown in Table 3.

\begin{tabular}{|l|l|}
\hline $\begin{array}{l}\text { Stage of } \\
\text { employment }\end{array}$ & \multicolumn{1}{|c|}{ Description } \\
\hline Early & $\begin{array}{l}\text { Organisations in the early stage of employing PPM have only recently } \\
\text { adopted the PPM methodology and have started managing a process } \\
\text { that should in time achieve the responsibilities of PPM. }\end{array}$ \\
\hline Intermediate & $\begin{array}{l}\text { Organisations in the intermediate stage of employing PPM are actively } \\
\text { employing and managing a process that partially achieves the } \\
\text { responsibilities of PPM as listed above. }\end{array}$ \\
\hline Mature & $\begin{array}{l}\text { Organisations in the mature stage have formally adopted PPM and are } \\
\text { actively employing and managing a process that achieves the key } \\
\text { criteria and responsibilities. }\end{array}$ \\
\hline
\end{tabular}

Table 3: Stages of PPM employment

Past research [2], [3], [4], [1] has found that the employment of PPM does not guarantee success. Some of the most common problems that are characteristic of project portfolios are those listed in Table 4. 
Too many active projects

Wrong projects (projects that do not add value to the organisation)

Projects are not linked to strategic goals

The project portfolio is unbalanced - e.g. too much development, not enough research; too much short-term, not enough long-term, etc.

Table 4: Common problems characteristic of project portfolios

We propose that the success of Project Portfolio Management employment can be measured by analysing the following:

(i) The improvement in strategy implementation and project delivery,

(ii) The improvement in the availability of resources for strategy implementation and project delivery, and

(iii) The reduction of characteristic problems experienced in project portfolios.

\section{RESEARCH METHODOLOGY}

\subsection{Research objectives}

This is an exploratory study of PPM employment by a selected group of South African technology organisations. The objectives of the research were (i) to evaluate the situation regarding the chasm that exists between strategy development and successful strategy implementation, (ii) to determine to what extent and with what success PPM is employed, and (iii) to determine if the PPM process can fill the chasm that exists between strategy development and successful attainment of strategic long- and short-term objectives.

The research questions associated with this study were:

Q1 What are the reasons for strategy failure?

Q2 What are the reasons for project delivery failure?

Q3 To what extent is PPM employed?

Q4 With what success is PPM employed?

\subsection{Research design}

The research design was a sample survey of project-intensive technology organisations in South Africa. Some fifty organisations that met this requirement were selected from eight industrial sectors (defence, engineering, mining, telecommunications, aerospace, information technology, automotive, and medical). The research population consisted of senior managers who were knowledgeable about strategy implementation in their organisations. Questionnaires were sent to a selection of 313 managers, and the response rate was $14 \%$ (44 responses from 32 organisations).

The data collection was done by means of a fixed-format questionnaire. Success rates for implementing of strategic plans and delivering projects were measured using five-category Likert scales: $0 \%-20 \%, 21 \%-40 \%, 41 \%-60 \%, 61 \%-80 \%, 81 \%-100 \%$.

Regarding the positions/roles of the respondents, $48 \%$ indicated that they were top executives, $23 \%$ were general managers, $18 \%$ were programme managers, and $11 \%$ were project managers. The spread of responses over different company sizes showed that the majority of the respondents were from organisations with a turnover of between R100 million and R1,000 million a year. All eight of the industrial sectors were represented in the sample. 


\section{RESULTS}

\subsection{Strategy failure}

'Strategy success' is defined as strategies that have been implemented such that the strategic goals have been achieved. Analysis of the survey data shows that the mean strategy implementation success rate of the sample was 66\% (confidence level $(95.0 \%)=$ $5.4 \%$ ). This implies that one in three of all strategy implementations failed. An analysis of the reasons why strategic plans of organisations fail showed that failure is primarily because strategic 'breakthrough' activities are not separated from daily work activities, and because of pre-occupied resources (see Figure 2). These two conditions represent $52 \%$ of respondents' reasons why strategies failed.

Pre-occupied resources

Daily work activities are not separated from strategic "breakthrough" activities

Project portfolios are not aligned with the strategic intent of the organization

Project portfolios are not aligned with the strategic intent of the organization

Lack of periodic progress review and process improvement

Our strategic plans are always implemented successfully

Lack of operational data analysis during strategic planning sessions

Vague vision statements with limited deployment in the organization

Vague mission statements with limited deployment in the organization

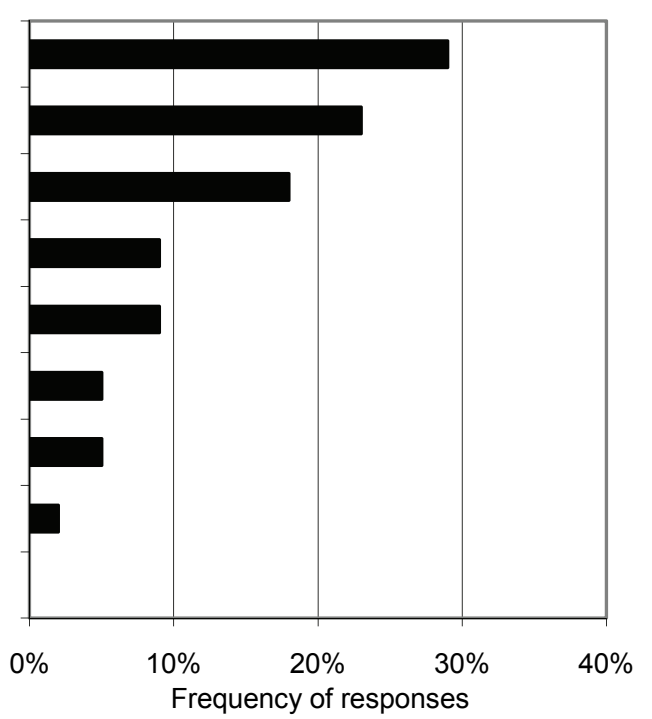

Figure 2: Reasons for strategy implementation failure

\subsection{Project delivery failure}

'Project delivery success' is defined as projects that were delivered on time, within budget, and within scope or specifications. Analysis of the survey data shows that the mean project delivery success rate of the sample was $68 \%$ (confidence level $(95.0 \%)=6.2 \%$ ). This indicates that almost one in three of all projects failed to deliver as expected. An analysis of the reasons for project delivery failure showed that it is primarily a result of running too many projects on too few resources (see Figure 3). These two conditions represent $44 \%$ of respondents' reasons why projects fail to deliver.

The characteristic problems of organisations' project portfolios were also evaluated by means of the survey questionnaire. The most common problem (44\% of respondents) of their project portfolios is that they have too many active projects. This response therefore correlates with the reasons for project failure. 


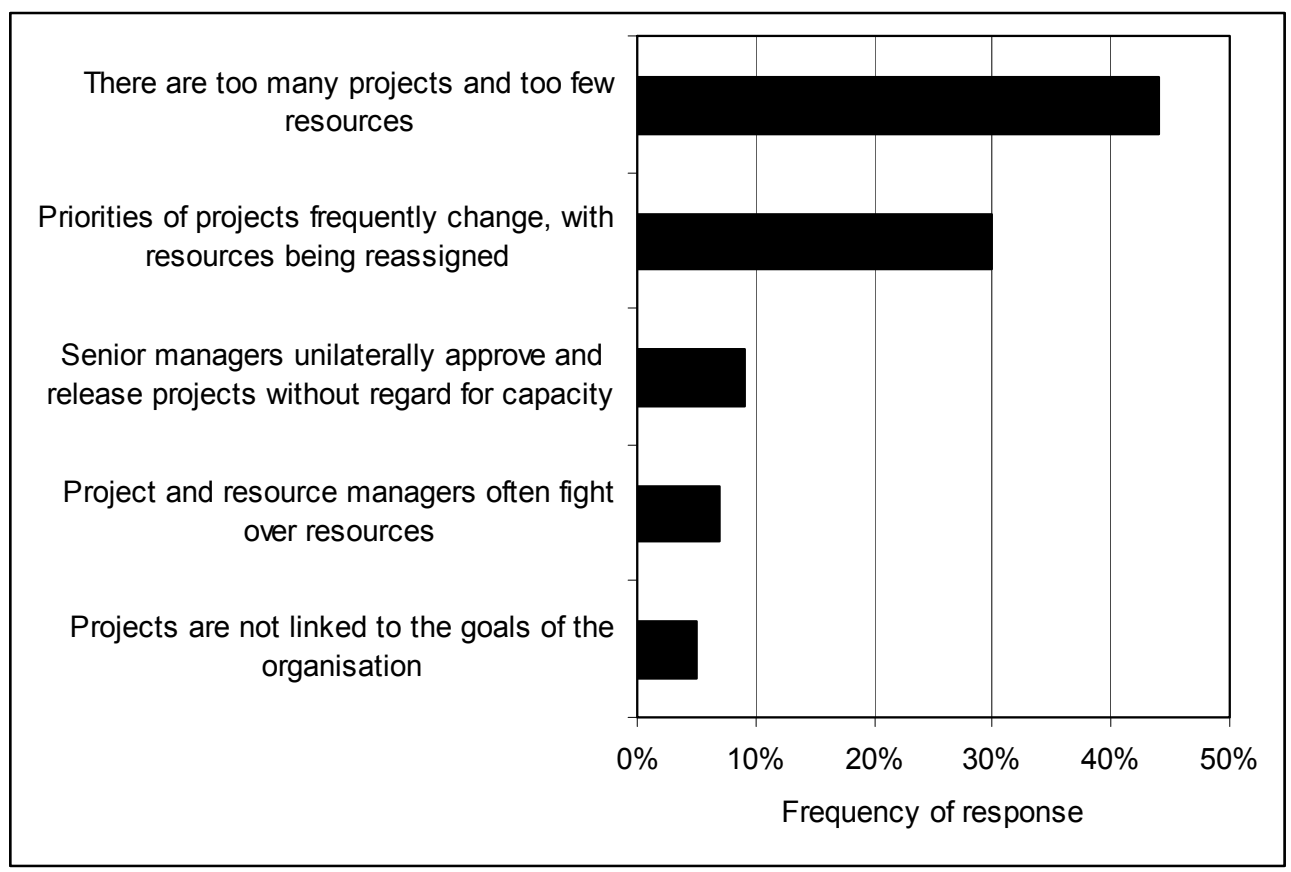

Figure 3: Reasons for project failure

\subsection{Project Portfolio Management employment}

This study found that $27 \%$ of the respondents' organisations are in the mature stage of employing PPM, $23 \%$ are in the intermediate stage, and $16 \%$ are in the early stage. Eleven percent of respondents indicated that they do not know their organisation's PPM employment status, whilst $23 \%$ indicated that they do not employ PPM at all.

\subsection{Project Portfolio Management employment: With what success?}

The success with which Project Portfolio Management is employed in South African technology organisations was measured by analyzing the data for:

(i) an improvement in strategy implementation and project delivery success rates,

(ii) an improved figure of resource availability for strategy implementation and project delivery, and

(iii) a change in the project portfolio characteristic problems for the different stages of PPM employment.

Figure 4 shows the mean strategy implementation success rates for the different stages of PPM employment. Although there is an increase in strategy implementation success rates with the implementation of PPM (Spearman correlation coefficient $=0.6$, ANOVA: $f=102$, $\mathrm{p}<0.05)$, those in the intermediate and mature stages of PPM employment have not reached the expected success rate of more than $80 \%$. 


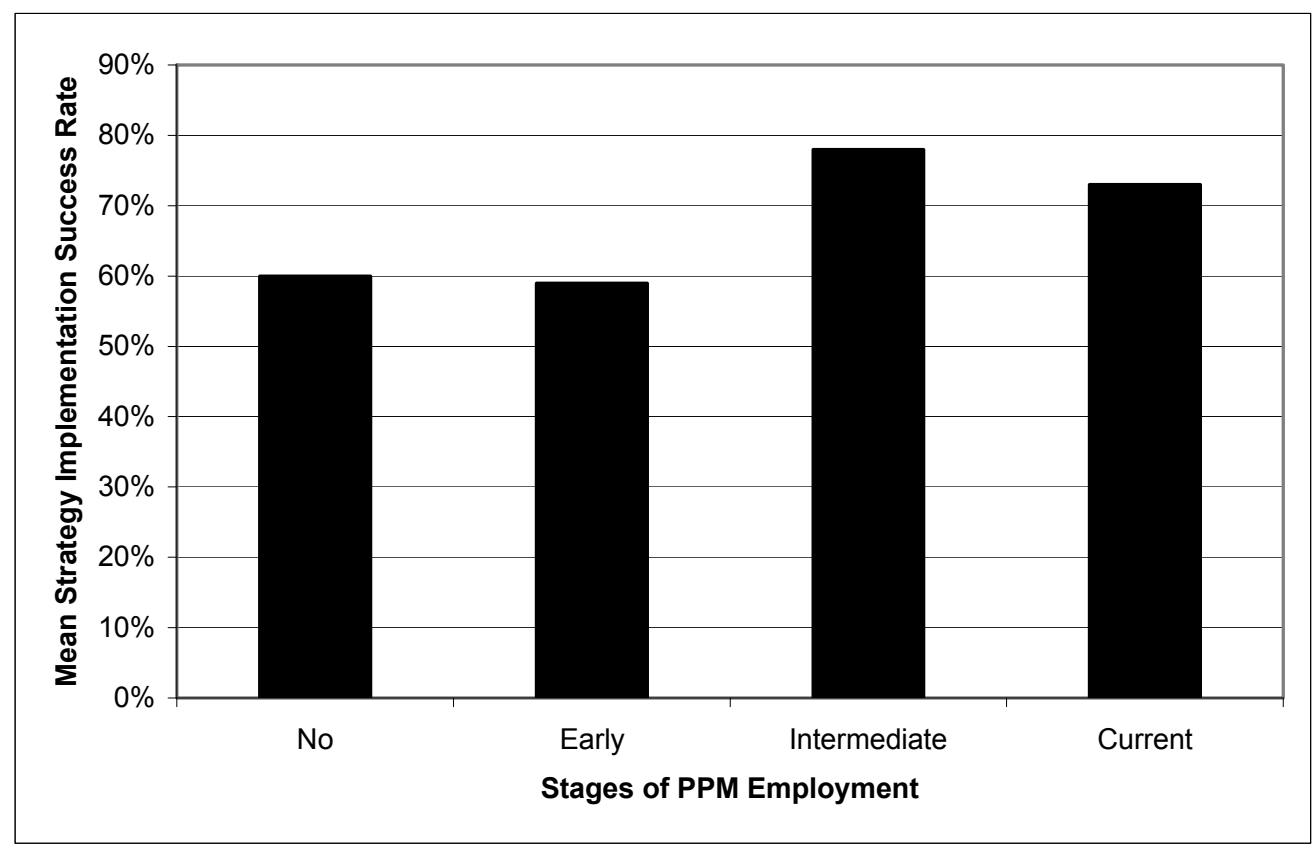

Figure 4: Strategy implementation success rates for different stages of PPM employment

Figure 5 shows the mean project delivery success rates for the different stages of PPM employment. There is an increase in project delivery success rates after the implementation of PPM (Spearman correlation coefficient $=1$, ANOVA: $f=265, p<0.05$ ) but the project delivery success rate of those that do not employ PPM is the same (approximately $75 \%$ ) as for those in the mature stage of PPM employment.

Analysis of the data for reasons for strategy implementation and project delivery failure showed that the most common reasons for the failure of most strategic plans and projects are that they have too many projects and too few resources. It was also found that the PPM responsibilities that are particularly poorly managed are portfolio analysis, finding ways to improve the portfolio, the evaluation of new opportunities against the current portfolio and comparatively with each other, taking into account the organisation's project execution capacity.

To determine whether the employment of PPM has improved resource availability for project delivery, the reasons for project delivery failure at the different stages of PPM were analysed. The analysis found that, for all the stages of PPM employment, the dominant reason why most of the PPM-employing organisations' projects fail are that they have too many projects in the project portfolio and too few resources.

The final measure of PPM employment success is a change in the project portfolio characteristic problems for the different stages of PPM employment. Analysis of the data showed that, for all the stages of PPM employment, the majority response was that there are too many active projects in the project portfolios. There is, however, a slight improvement regarding this problem from the intermediate stage of implementation $(60 \%)$ to the mature stage of implementation (50\%). The fact that the data shows that there are too many active projects even in the mature stage of PPM employment is proof that the organisations are not fully employing and managing their key PPM responsibilities. 


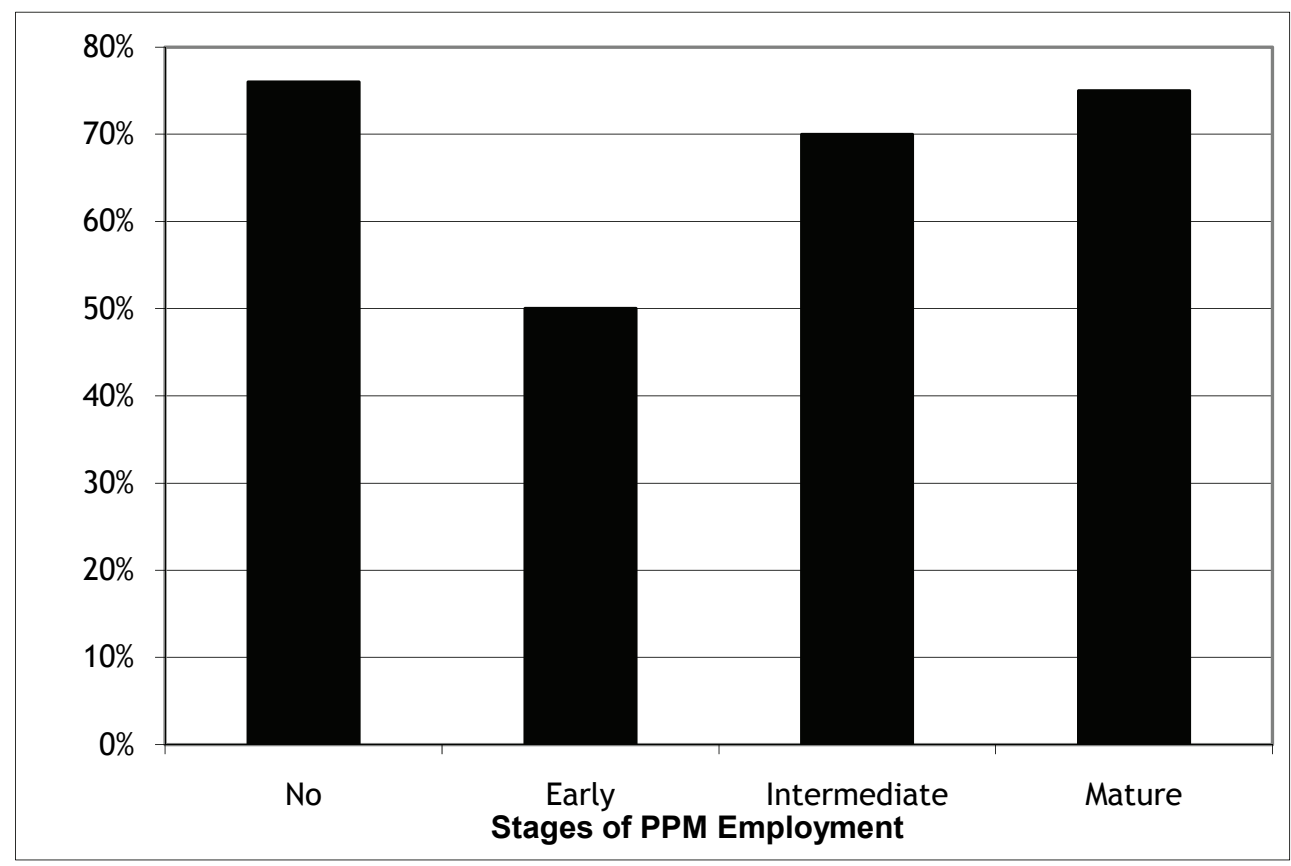

Figure 5: Project delivery success rate for different stages of PPM employment

\section{CONCLUSIONS AND RECOMMENDATIONS}

\subsection{Reasons for strategy failure}

This study found that one in three of all strategy implementations fail. This indicates that there is a significant chasm between strategy development and successful strategy implementation. The reasons why strategic plans of organisations fail are primarily a result of strategic 'breakthrough' activities not being separated from daily work activities, and pre-occupied resources. Note that these two conditions are not independent variables. When strategic 'breakthrough' activities are not separated from daily work activities, resources become pre-occupied with daily work activities. This is the very reason why the Project Portfolio Management methodology was originally developed. According to Pete Babich [2], the best way to separate daily activities from strategic 'breakthrough' activities is to develop effective mission and vision statements. The existence, development, and updating of mission and vision statements was subsequently analysed, and it was found that $15 \%$ of respondents reported an absence of effective mission and vision statements in their organisations. The findings of this study support the previous work of Martinelli and Waddell [1], Babich [2], Dietrich and Lehtonen [3], and Knutson [4], who have also found that daily work activities not separated from strategic 'breakthrough' activities and pre-occupied resources are some of the most common reasons why strategic plans are not implemented successfully.

\subsection{Reasons for project delivery failure}

This study found that almost one in three of all projects failed to deliver as expected. Failure is primarily a result of too many projects and too few resources. Note that these two conditions are also not independent variables. When an organisation has too many projects it results in a shortage of resources. PPM addresses this problem by project selection based on impact on resources, and monitoring the planning and execution of chosen projects. Previous research by Martinelli and Waddell [1], Babich [2], Dietrich and 
Lehtonen [3], and Knutson [4] also found that too many active projects is one of the most common problems that characterise project portfolios.

This study also found that the most characteristic problem of project portfolios is too many active projects. Too many active projects that do not add strategic value to the organisation pre-occupy valuable resources. Michael Greer [14] also lists too many active projects in a portfolio as a major contributing factor for project failure. According to Greer, too many projects result in a high turnover of resources due to 'burn out' of key project contributors because they are working on too many projects and are spending too many overtime hours. The study found that one of the reasons why there are too many projects in organisations' project portfolios, is that a number of organisations do not have a management system in place to determine a viable project mix that is capable of meeting the goals of the organisation. A number of respondents also indicated that they do not balance their project portfolios, monitor the planning and execution of projects, analyze portfolio performance to find ways to improve it, or evaluate new opportunities against the current portfolio and comparatively with each other, taking into account the organisation's project execution capacity.

\subsection{To what extent is PPM employed?}

This study found that $66 \%$ of respondents indicated that their organisations are in some stage of PPM employment. This figure for South African technology organisations is similar to the findings of the study that was performed by the Centre for Business Practices [15] in the USA. More than half of the respondents in their study $(64.1 \%)$ indicated that they have a PPM process in place. This US-based study also found that organisations that have no PPM process in place are more likely to be small in size $(21.7 \%$ with sales under $\$ 10$ million; $21.7 \%$ with sales over $\$ 3$ billion) compared with organisations that have PPM processes in place $(10.9 \%$ with sales under $\$ 10$ million; $35.9 \%$ with sales over $\$ 3$ billion). This study found that the majority $(40 \%)$ of South African organisations not employing PPM are also small in size (R10m - R100m).

\subsection{With what success is PPM employed?}

This study found that there is a significant increase in strategy implementation success rates with the implementation of PPM. However, despite this improvement, those in the intermediate and mature stages of PPM employment have not reached the expected success rates of $>80 \%$.

It was also found that there is an increase in project delivery success rates after the implementation of PPM. However, the project delivery success rate of those that do not employ PPM is the same as for those in the mature stage of PPM employment. This finding was unexpected. Some of these high-performing firms that did not employ PPM were asked about this, and indicated that they were using other methodologies such as enterprise programme management [16] and did not feel the need to employ PPM.

This study found that the most common reasons why strategic plans and projects fail are too many projects and too few resources. Even those organisations that have employed PPM - including those in the mature stage of PPM employment - reported that they still have too many projects in their project portfolios and too few resources. According to the theory of PPM, organisations that are employing PPM and have too many projects and too few resources do not employ and manage the PPM responsibilities listed in section 2 properly. We found that the PPM responsibilities that are particularly poorly managed are portfolio analysis to find ways to improve the portfolio, and the evaluation of new opportunities against the current portfolio and comparatively with each other, taking into account the organisation's project execution capacity. The end result is failure to capitalise on the advantages that PPM offers. 


\subsection{Project Portfolio Management: A way of crossing the chasm}

In conclusion, this study found that the employment of PPM in organisations can lead to an improvement in strategy implementation and project delivery success rates - in other words, crossing the chasm between strategy development and strategy implementation. South African technology organisations that employ PPM have, however, shown a poor success rate for both strategy implementation and project delivery. The study found that this poor success rate is a result of organisations not fully employing and managing the key PPM responsibilities.

These findings are based on a sample survey of 44 respondents in 32 project-intensive technology organisations in South Africa. Although the sample was drawn from eight industrial sectors, some were represented by only a few responses, and therefore no meaningful conclusions could be made regarding any particular sector. The findings are preliminary, and further research will be conducted to increase the sample size and thus the generalisability of the results.

\section{REFERENCES}

[1] Martinelli, R. \& Waddell, J. 2005. Aligning program management to business strategy. http: / /www.pmforum.org, visited on 8 March 2006.

[2] Babich, P. 1995. Why strategic plans fail. Total Quality Engineering Inc. http://www.tqe.com, visited on 8 March 2006.

[3] Dietrich, P. \& Lehtonen, P. 2005. Successful management of strategic intentions through multiple projects: Reflections from empirical study. International Journal of Project Management 23:386-391.

[4] Knutson, J. 2003. Aligning strategic planning with project management. PM Network, Vol. 17, No. 4:66.

[5] Grundy, T. 1998. Strategy implementation and project management. International Journal of Project Management, 16 (1): 43-50.

[6] Diab, P. 1998. Strategic Planning+Project Management=Competitive Advantage. PM Network, Vol. 12, No. 7:25-28.

[7] Pellegrinelli, A. 1997. Programme management: Organising project-based change, International Journal of Project Management, 15 (3): 141-149.

[8] Cleland, D. \& King, W. (eds) 1988. The project management handbook, $2^{\text {nd }}$ edition. New York: Van Nostrand Reinhold.

[9] Artto K., Martinsuo M. \& Aalto T. 2001. Project portfolio management: Strategic management through projects, Project Management Association Finland, Helsinki, Finland.

[10] Cooper, R., Edgett, S. \& Kleinschmidt, E. 1997. Portfolio management in new product development: Lessons from the leaders I. Research Technology Management 40 (5) $16-28$.

[11] Morris, P. \& Pinto, J. K. 2007. The Wiley guide to project, program, and portfolio management, John Wiley \& Sons.

[12] Kendall, G. I. \& Rollins, S. C. 2003. Advanced project portfolio management and the PMO. J. Ross Publishing, Inc: Florida.

[13] Ciliberti, R. 2005. Using Project Portfolio Management to improve business value. http://www-106.ibm.com, visited on 8 March 2006.

[14] Greer, M. 2006. What's Project Portfolio Management (PPM) \& why should project managers care about it? http: / /www. michaelgreer.com, visited on 9 March 2006.

[15] Center for Business Practices. 2006 Project Portfolio Management: A benchmark of current business practices, http://www.cbponline.com, visited on 10 March 2006.

[16] Williams, D. \& Parr, T. 2004. Enterprise Programme Management: Delivering value. Palgrave Macmillan: New York. 